\title{
Implementasi Teknik Artificial Intelegent Rough Set Dalam Pengambilan Keputusan Pada Proses Penentuan Kelulusan Pelamaran Pekerjaan
}

\author{
Romi Wijaya, S.Kom, M.Kom \\ Magister Ilmu Komputer, Universitas Putra Indonesia "YPTK", Padang \\ email:wijayaromi@upiyptk.ac.id
}

\begin{abstract}
Abstrak: Penelitian ini dilakukan untuk mempelajari teknik Artificial Intelegent Rough Set yang diimplementasikan dalam Sistem pengambilan keputusan pada UD.ROMI.data dikumpulkan melalui observasi dan interview yang dilakukan kepada pemilik perusahaan yang bersangkutan. Selanjutnya data dianalisa untuk menentukan data yang dibutuhkan dalam proses penentuan keputusan. Dari eksperimen yang dilakukan dengan menggunakan teknik Artificial Intelegent Rough Set serta menggunakan Software Rosetta dapat memberikan hasil yang akurat dalam mengambil keputusan.
\end{abstract}

Kata Kunci: Artificial Intelegent Rough Set, Software Rosetta

Abstract: This research was conducted to study Artificial Intelegent Rough Set technique implemented in decision making system at UD.ROMI. data collected through observation and interviews conducted to the owner of the company concerned. Further data is analyzed to determine the data needed in the decision making process. From experiments conducted using Artificial Intelegent Rough Set technique and using Rosetta Software can give accurate results in making decisions.

Keyword: Artificial Intelegent Rough Set, Software Rosetta

\section{PENDAHULUAN}

Perusahaan adalah sebuah unit kegiatan produksi yang mengolah sumber daya ekonomi untuk menyediakan barang dan jasa bagi masyarakat dengan tujuan memperoleh keuntungan dan memuaskan kebutuhan masyarakat.

Di dalam Perusahaan kita perlu untuk menentukan klasifikasi seorang pekerja dengan tujuan untuk menilai Propesionalisme karyawan, guna untuk meningkatkan mutu para pekerja dalam sebuah perusahaan.

Berdasarkan definisi di atas, maka penulis menyimpulkan bahwa perekrutan calon karyawan merupakan proses pengalokasian sumber daya yang ada sesuai dengan fungsinya untuk mencapai suatu tujuan. Dengan demikian penyeleksian calon karyawan merupakan pengokasian sumber daya perusahaan serta waktu untuk mendapatkan calon karyawan yang lebih baik.

M Nordin A Rahman, Yuzarimi M Lazim, Farham Mohamed (2011) memberikan kesimpulan bahwa Rough Set berguna untuk menjelajahi data multimedia dan kesederhanaan untuk membangun klasifikasi data multimedia, serta membantu untuk meningkatkan kinerja data multimedia dalam proses pengorganisasian. Chen, Cheng and Hsieh (2009) juga melakukan penelitian bahwa teori Rough Set dapat digunakan untuk preprocess data dan mengurangi dimensi terhadapat kepadatan data.

Sengupta and Das (2012) menggunakan metode Rough Set untuk menghitung nilai atribut yang telah ditetapkan dan meminimalkan tabel atribut sehingga atribut terebut mirip dengan jumlah maksimum atribut. Tripathy, Acharjya (2011) memberikan kesimpulan bahwa Rough Set dapat membantu dalam proses diagnosis medis untuk mengambil keputusan dari gejala - gejala penyakit, untuk memudahkan dokter dalam menangani komplikasi aspek diagnosis.

Teknologi kecerdasan buatan dipelajari dalam bidang-bidang, seperti: robotika, penglihatan komputer (Computer 
Vision), jaringan saraf tiruan (Artifical Neural System), pengolahan bahasa alami (Natural Language Processing), pengenalan suara (Speech Recognition), dan Sistem Pakar (Expert System) (Hariyadi, 2016)

\section{KAJIAN LITERATUR}

\subsection{Knowledge Discovery in Database}

Proses Knowledge Discovery in Database (KDD) terdiri dari beberapa langkah-langkah, antara lain : (Angga Ginanjar Mabrur, Riani Lubis (2012))

1. Data Selection (pemilihan data), pemilihan data dari sekumpulan data operasional perlu dilakukan sebelum tahap penggalian informasi dalam KDD dimulai.

2. Preprocessing, sebelum proses Data Mining dapat dilaksanakan, perlu dilakukan proses cleaning dengan tujuan untuk membuang duplikasi data, memeriksa data yang inkonsisten, dan memperbaiki kesalahan pada data, seperti kesalahan cetak (tipografi). Juga dilakukan proses enrichment, yaitu proses "memperkaya" data yang sudah ada dengan data atau informasi lain yang relevan dan diperlukan untuk KDD, seperti data atau informasi eksternal.

3. Data Transformation (transformasi data), proses coding pada data yang telah dipilih, sehingga data tersebut sesuai untuk proses Data Mining. Proses coding dalam KDD merupakan proses kreatif dan sangat tergantung pada jenis atau pola informasi yang akan dicari dalam database.

4. Data Mining, suatu proses di mana metoda diterapkan untuk menemukan pengetahuan berharga dan tersembunyi di dalam database. Dalam hal inilah teknikteknik Artificial Intelligence dibutuhkan.

5. Interpretation / Evaluation, pola informasi yang dihasilkan dari proses Data Mining perlu ditampilkan dalam bentuk yang mudah dimengerti oleh pihak yang berkepentingan. Tahap ini merupakan bagian dari proses KDD yang disebut dengan interpretation. Tahap ini mencakup pemeriksaan apakah pola atau informasi yang ditemukan bertentangan dengan fakta atau hipotesa yang ada sebelumnya atau tidak.Dari pengertian diatas dapat disimpulkan bahwa metode analisa dan desain berorientasi objek merupakan suatu metode untuk memeriksa kebutuhan dari sudut pandang kelas-kelas dan objek kemudian mempelajari permasalahan dengan menspesifikasikannya atau mengobservasi permasalahan tersebut sesuai dengan kombinasi antara struktur data dan perilaku dalam satu entitas. Metode analisa dan desain berorientasi objek menawarkan sebuah kerangka kerja yang baik untuk skenario (Jakimi dan Koutbi, 2011).

\subsection{Data Mining}

Data mining adalah proses yang mempekerjakan satu atau lebih teknik pembelajaran komputer (mechine learning) untuk menganalisis data dan mengekstraksi pengetahuan (knowledge) secara otomatis menurut Fajar Astuti Hermawati (Nurhayati, 2014).

Tahapan - tahapan yang dilakukan dalam proses Data Mining (Adi Sucipto, 2015 ) :

1. Data Cleaning, merupakan proses menghilangkan noise dan data yang tidak konsisten atau data yang tidak relevan.

2. Data Integration, merupakan proses penggabungan data ke dalam satu database di mana terkadang proses Data Mining yang akan dilakukan memerlukan data lebih dari satu database atau memerlukan pemprosesan menggunakan database lain.

3. Data Transpormation, merupakan pengubahan data atau penggabungan data yang dilakukan sebelum akan dilakukan proses Data Mining. Karena dalam proses Data Mining dalam beberapa metode membutuhkan format data yang khusus sebelum data dialokasikan.

4. Aplikasi Teknik Data Mining, merupakan salah satu bagian dari proses Data Mining. 
5. Interpretasi / Evaluasi, merupakan pola yang menentukan hasil dari teknik Data Mining berupa pola-pola yang khas maupun model prediksi dievaluasi untuk menilai apakah hipotesa memang benarbenar tercapai.

6. Knowladge / Pengetahuan, merupakan presentasi pola yang ditemukan untuk menghasilkan aksi tahap terakhir dari proses Data Mining dan bagaimana memformulasikan keputusan atau aksi dari hasil analisa yang didapat.

\subsection{Teknik Artificial Intelligence Rought Set}

Menurut Obadi, et al. (Nurhayati, 2014) mengatakan bahwa Rough set dikembangkan oleh Zdizslaw Pawlak yang dapat digunakan sebagai alat matematikal untuk menangani ketidakjelasan dan ketidakpastian. Dan telah berhasil diterapkan dalam berbagai tugas, seperti fitur seleksi / ekstraksi, sintesis aturan dan klasifikasi, penemuan pengetahuan dan lain-lain. Toleransi Model Rough set mempekerjakan relation toleransi bukan sebuah eqivalence hubungan dalam model Rough set original.

\section{METODE PENELITIAN}

Penelitian ini dapat digolongkan kepada model penelitian eksperimen multivariate yaitu analisa terhadap komponen utama yang melibatkan banyak variabel dan berdimensi cukup besar.Dalam hal ini perlu dilakukan penyederhanaan struktur dan dimensi untuk mempermudah interprestasi dari seluruh data/informasi yang ada. Pada penelitian ini, semua proses mengacu kepada teori teknik Rough Set yang dikembangkan oleh Pawlak pada awal 1980.

\subsection{Kerangka Kerja}

Kerangka kerja yang digunakan dalam penelitian ini dapat digambarkan seperti terlihat pada gambar 3.1 berikut :

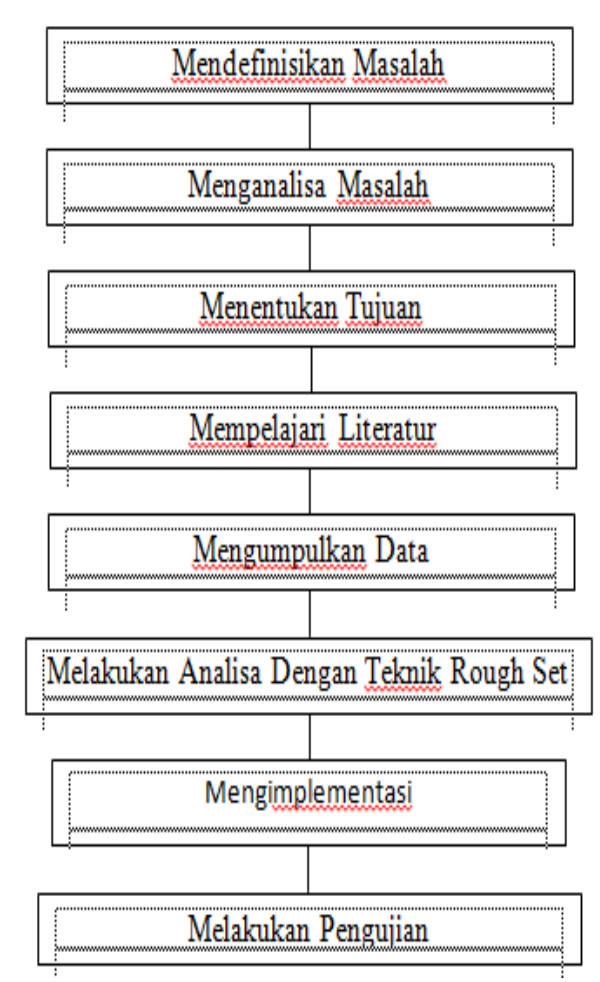

Gambar 1 : Kerangka Kerja Penelitian

\section{Analisa dan Perancangan}

\subsection{Analisis Sistem}

Pada tahap analisa dan perancangan ditujukan untuk mempelajari cara pegambilan keputusan pada UD.ROMI dan memberikan masukan untuk pengambilan keputusan selanjutnya. Penganalisaan dilakukan berdasarkan fakta dan data yang didapat di UD.ROMI.

\subsection{Rancangan Umum Sistem Pendukung Keputusan \\ Pada bagian ini penulis akan} menjelaskan arsitektur dari sistem pendukung keputusan dan analisa data penentuan usulan pelamar pekerjaan yang terdiri dari rancangan umum dan komponenkomponen yang digunakan. Untuk lebih jelasnya dapat dilihat pada gambar 


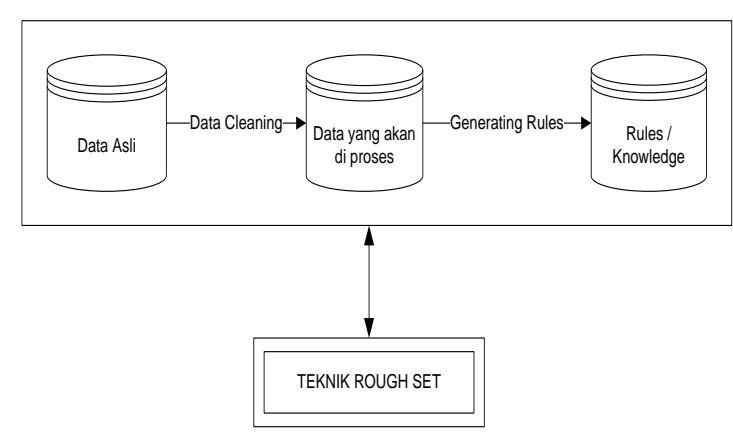

\section{Gambar 2 Rancangan Umum Sistem Pengambilan Keputusan}

\subsection{Pengolahan Data}

Pada Tahap pengolahan data penulis akan menganalisa data asli yang telah didapatkan pada proses pengumpulan data pada UD.ROMI dengan menggunakan teknik Rough Set, dalam tahap ini akan dijelaskan gambaran awal mengenai datadata yang akan diproses dan membahas teknik-teknik yang digunakan dalam Artificial Intelegent RoughSet.

\subsubsection{Decision System}

Dari data-data yang telah didapat maka penulis dapat melakukan pengelompakan terhadap data-data yang akan digunakan dalam proses penelitian, adapun data-data yang akan dikelola terdiri dari lima atribut di mana satu atribut dinyatakan untuk Equeivalence Relation (No), tiga atribut untuk kondisi (Condition) dan 1 atribut untuk atribut keputusan (Decision).

Tabel 1 Information System

\begin{tabular}{|l|l|l|l|l|}
\hline No & Pendidikan & Pengalaman & Hasil Tes & Keputusan \\
\hline 1 & SMP & Ada & Kurang Baik & Tidak Lulus \\
\hline 2 & SMU & Ada & Baik & Lulus \\
\hline 3 & SMP & Tidak & Kurang Baik & Tidak Lulus \\
\hline 4 & SMU & Ada & Baik & Lulus \\
\hline 5 & SMU & Tidak & Baik & Lulus \\
\hline 6 & SMP & Ada & Kurang Baik & Tidak Lulus \\
\hline 7 & SMU & Ada & Baik & Lulus \\
\hline 8 & SMU & Tidak & Baik & Lulus \\
\hline 9 & SMP & Ada & Kurang Baik & Tidak Lulus \\
\hline 10 & SMU & Ada & Baik & Lulus \\
\hline 11 & SMU & Tidak & Baik & Lulus \\
\hline 12 & SMP & Ada & Kurang Baik & Tidak Lulus \\
\hline 13 & SMU & Tidak & Baik & Lulus \\
\hline 14 & SMP & Tidak & Kurang Baik & Tidak Lulus \\
\hline 15 & SMU & Tidak & Kurang Baik & Tidak Lulus \\
\hline
\end{tabular}

\subsubsection{Equivalence Class}

Dalam menyelesaikan Equivalence Class penulis mengelompokkan objek-objek yang sama (Pendidikan, Pengalaman, Hasil Tes, Keputusan) untuk memudahkan dalam mencari hasil kelulusan pelamar, dan melakukan perubahan pada Equivalence Class (No) dengan memberikan Variabel (EC1-EC5), sehingga data yang ada dapat disederhanakan Kembali.

\section{Tabel 2 Equivalence Class}

\begin{tabular}{|c|c|c|c|c|c|}
\hline Class & Pendidiknn & pengalaman & How Tes & Keputusan & Jumlah \\
\hline $\mathrm{ECl}$ & SMP & Ada & Kurang Balk & Tidak:Lulus & 4 \\
\hline$E C 2$ & SMOU & Ada & Budk & Luths & 4 \\
\hline$E C 3$ & SMP & Tidel & Kurang Ba & Tidak Lilus & 2 \\
\hline ECt & SMU & Iddek & Bajk & Lins & 4 \\
\hline ECS & SMO & Iddak & Krang Badk & TidakLilus & 1 \\
\hline
\end{tabular}

Setelah Numerical Representation ditentukan maka Equivalence Class (Transformasi) yang dihasilkan dapat dilihat pada tabel.

\section{Tabel 3 Equivalen Class (Transformasi)}

\begin{tabular}{|l|l|l|l|l|l|}
\hline Class & Pendidizan & Pengalaman & Hasil Tes & Keputasan & Jumlah \\
\hline EC1 & 1 & 2 & 1 & 1 & 4 \\
\hline EC2 & 2 & 2 & 3 & 5 & 4 \\
\hline EC3 & 1 & 1 & 1 & 1 & 2 \\
\hline EC4 & 2 & 1 & 3 & 5 & 4 \\
\hline EC5 & 2 & 1 & 1 & 1 & 1 \\
\hline
\end{tabular}

\subsubsection{Discernibility Matrix}

Dalam penyelesaian proses Discernibility Matrix penulis melakukan perbandingan setiap Class dan melakukan perubahan pada atribut seperti : Pendidikan $\left(E_{1}\right)$, Pengalaman $\left(E_{2}\right)$, Hasil Tes $\left(E_{3}\right)$, Keputusan $\left(\mathrm{EC}_{4}\right)$, dan Jumlah $\left(\mathrm{EC}_{5}\right)$, apabila terdapat perbedaan pada Attribute Class, maka tuliskan pada tabel Discerdibility Matrix $(A B)$, sedangkan jika semua atribut sama maka tuliskan dengan tanda kali $(X)$.

\section{Tabel 4 Discernibility Matrix}

\begin{tabular}{|l|l|l|l|l|l|}
\hline & ECl & EC2 & EC3 & EC4 & EC5 \\
\hline EC1 & X & AC & B & ABC & AB \\
\hline EC2 & AC & X & ABC & B & BC \\
\hline EC3 & B & ABC & X & AC & A \\
\hline EC4 & ABC & B & AC & X & C \\
\hline EC5 & AB & BC & A & C & X \\
\hline
\end{tabular}




\subsubsection{Discernibility Matrix Modulo D}

Dalam penyelesaian proses Discernibility Matrix Modulo D penulis melakukan perbandingan terhadap sekumpulan atribut yang berbeda antara objek yang satu dengan yang lainnya dan juga berbeda atribut keputusan. Berdasarkan tabel 3, bandingkan setiap class berdasarkan decision/keputusan, jika keputusan sama maka tuliskan tanda kali (X).

Tabel 5. Discernibility Matrix Modulo D

\begin{tabular}{|l|l|l|l|l|l|}
\hline & EC1 & EC2 & EC3 & EC4 & EC5 \\
\hline EC1 & X & AC & X & ABC & X \\
\hline EC2 & AC & X & ABC & X & BC \\
\hline EC3 & $\mathrm{X}$ & $\mathrm{ABC}$ & $\mathrm{X}$ & $\mathrm{AC}$ & $\mathrm{X}$ \\
\hline EC4 & $\mathrm{ABC}$ & $\mathrm{X}$ & $\mathrm{AC}$ & $\mathrm{X}$ & $\mathrm{C}$ \\
\hline EC5 & $\mathrm{X}$ & $\mathrm{BC}$ & $\mathrm{X}$ & $\mathrm{C}$ & $\mathrm{X}$ \\
\hline
\end{tabular}

\subsubsection{Reduct}

Untuk mendapatkan hasil Reduct langkah selanjutnya adalah penyeleksian Attribute Minimal (Interesting Attribute) dari sekumpulan atribut kondisi dengan menggunakan Prime Implicant fungsi Boolean. Kumpulan dari semua Prime Implicant mendeterminasikan Sets Of Reduct. Discernibility Matrix Modulo D pada tabel 6 dapat ditulis sebagai formula CNF.

\section{Tabel 6 Reduce}

\begin{tabular}{|c|c|c|c|}
\hline Class & CNF of Function Boolean & $\begin{array}{l}\text { Prime } \\
\text { Implicant }\end{array}$ & Reduce \\
\hline $\mathrm{ECl}$ & $(\mathrm{AvC})^{N}(\mathrm{AvBvC})$ & $\mathrm{ANC}$ & $\{A\},\{C\}$ \\
\hline $\mathrm{EC} 2$ & $(\mathrm{AvC})^{\prime}(\mathrm{AvBvC})^{\prime}(\mathrm{BrC})$ & $(A v B) C$ & $\{A B\},\{C\}$ \\
\hline $\mathrm{EC} 3$ & $(A v B+C))(A v C)$ & $\mathrm{AvC}$ & $\{\mathrm{A}\},\{\mathrm{C}\}$ \\
\hline EC4 & $\left(\mathrm{AvBvC} Y(\mathrm{AvC}){ }^{\prime} \mathrm{C}\right.$ & $\mathrm{C}$ & $\{C\}$ \\
\hline EC5 & $(\mathrm{BvC})^{\prime} \mathrm{C}$ & $\mathrm{C}$ & $\{C\}$ \\
\hline
\end{tabular}

\subsubsection{Generating Rules}

Setelah mendapatkan Reduce, maka dapat ditarik kesimpulan dan menentukan RuleRule yang telah didapat, dengan menyesuaikan Reduce pada setiap Equivalen Class dengan mengacu pada tabel 2.

a. Class EC1 menghasilkan Prime Implicant $\{A\},\{C\}$, Rulenya adalah :

1. Jika Pendidikan = SMP maka Keputusan $=$ Tidak Lulus

2. Jika Hasil Tes $=$ Kurang Baik maka Keputusan $=$ Tidak Lulus

b. Class EC2 menghasilkan Prime Implicant $\{\mathrm{A}, \mathrm{B}\},\{\mathrm{C}\}$, Rulenya adalah :
3. Jika Pendidikan $=$ SMU dan Pengalaman $=$ Ada maka Keputusan $=$ Lulus

4. Jika Hasil Tes $=$ Baik maka Keputusan $=$ Lulus

c. Class EC3 menghasilkan Prime Implicant $\{\mathrm{A}\},\{\mathrm{C}\}$, Rulenya adalah

5. Jika Pendidikan = SMP maka Keputusan $=$ Tidak Lulus

6. Jika Hasil Tes $=$ Kurang Baik maka Keputusan $=$ Tidak Lulus

d. Class EC4 menghasilkan Prime Implicant $\{\mathrm{C}\}$, Rulenya adalah :

7. Jika Hasil Tes = Baik maka Keputusan $=$ Lulus

e. Class EC1 menghasilkan Prime Implicant

$\{C\}$, Rulenya adalah :

8. Jika Hasil Tes $=$ Kurang Baik maka Keputusan $=$ Tidak Lulus

Dari Rule-Rule dan data yang ada, dapat diambil keputusan dengan menggunakan logika OR, sehingga Rule-Rule yang didapat dengan menggunakan logika OR adalah :

1. Jika Pendidikan $=$ SMU maka Keputusan $=$ Lulus OR Keputusan $=$ Tidak Lulus

2. Jika Pendidikan $=$ SMU dan Pengalaman $=$ Tidak maka Keputusan $=$ Lulus $\mathrm{OR}$ Keputusan $=$ Tidak Lulus 


\section{IMPLEMENTASI DAN PENGUJIAN}

\subsection{Data Pengujian}

adapun keseluruhan data dapat dilihat pada tabel 7.

\begin{tabular}{|c|c|c|c|}
\hline \multicolumn{4}{|c|}{ Tabel 7 Data Keseluruhan } \\
\hline No Pendidikan & Pengalaman & Hasil Tes & Keputusan \\
\hline $1 \mathrm{SMP}$ & Ada & Kurang Baik & Tidak L ulus \\
\hline $2 \mathrm{SMP}$ & Ada & Kurang Baik & Tidak Lulus \\
\hline $3 \mathrm{SMU}$ & Ada & Baik & Luhus \\
\hline $4 \mathrm{SMU}$ & Ada & Baik & Luhus \\
\hline $5 \mathrm{SMP}$ & Tidak & Kurang Baik & Tidak L uius \\
\hline $6 \mathrm{SMU}$ & Ada & Baik & Luhus \\
\hline $7 \mathrm{SMU}$ & Tidak & Baik & Luhus \\
\hline $8 \mathrm{SMP}$ & Tidak & Kurang Baik & Tidak L ulus \\
\hline $9 \mathrm{SMP}$ & Tidak & Kurang Baik & Tidak L uius \\
\hline $10 \mathrm{SMU}$ & Ada & Baik & Luhus \\
\hline $11 \mathrm{SMU}$ & Ada & Baik & Luhus \\
\hline $12 \mathrm{SMU}$ & Tidak & Baik & Luhus \\
\hline $13 \mathrm{SMP}$ & Ada & Kurang Baik & Tidak Lulus \\
\hline $14 \mathrm{SMU}$ & Ada & Baik & Luhus \\
\hline $15 \mathrm{SMP}$ & Ada & Kurang Baik & Tidak L ulus \\
\hline $16 \mathrm{SMU}$ & Tidak & Baik & Luhus \\
\hline $17 \mathrm{SMP}$ & Ada & Kurang Baik & Tidak Lulus \\
\hline $18 \mathrm{SMU}$ & Tidak & Baik & Luhus \\
\hline $19 \mathrm{SMU}$ & Ada & Baik & Luhus \\
\hline $20 \mathrm{SMU}$ & Tidak & Baik & Luhus \\
\hline $21 \mathrm{SMP}$ & Ada & Kurang Baik & Tidak L ulus \\
\hline $22 \mathrm{SMU}$ & Tidak & Baik & Luhus \\
\hline $23 \mathrm{SMP}$ & Ada & Kurang Baik & Tidak L ulus \\
\hline $24 \mathrm{SMU}$ & Ada & Baik & Luhus \\
\hline $25 \mathrm{SMU}$ & Tidak & Baik & Luhus \\
\hline $26 \mathrm{SMP}$ & Ada & Kurang Baik & Tidak L ulus \\
\hline $27 \mathrm{SMU}$ & Tidak & Kurang Baik & Tidak Lulus \\
\hline
\end{tabular}

\subsection{Langkah-langkah}

Software Rosetta

Pengujian

Untuk membuktikan kebenaran pada tahap analisa dan pengujian scara manual, maka diperlukan pengujian dengan menggunakan Software Rosetta.

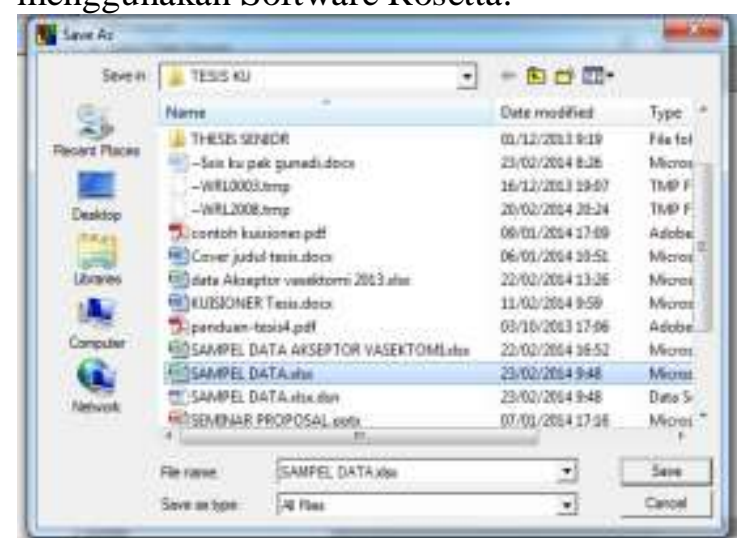

Gambar 2 :Directori Penyimpanan Data Source

Gambar 2 menggambarkan tentang lokasi penyimpanan File Rosetta. Setelah melakukan proses penyimpanan.

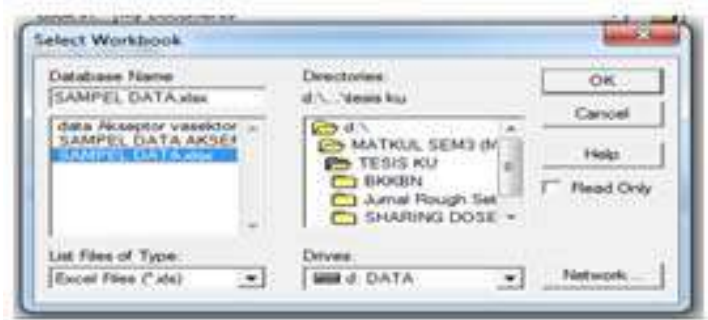

Gambar 3 Pemilihan File Decision System Pada penelitian ini, penulis menggunakan "DataPelamar.xls" sebagai data processing. Untuk tahapan selanjutnya mencari di mana letak data Source yang telah di Create pada tahapan sebelumnya.

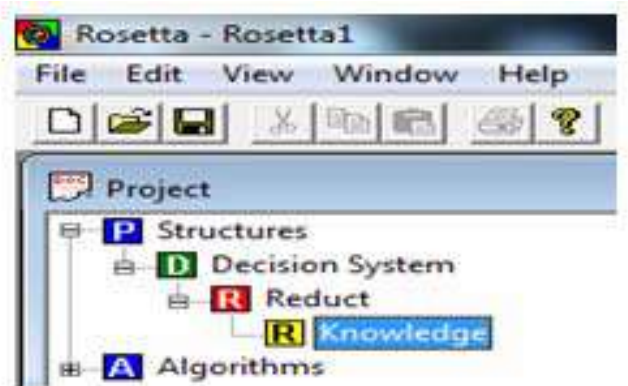

\section{Gambar 4 :Sheet Of Decision System}

Gambar 4 mendeskripsikan Project baru dari Rosetta-nya dan menyatakan dengan benar data yang diimpor telah masuk ke dalam sistem.

Untuk melihat hasil dari proses Reduct yaitu dengan cara "Double Click" icon Reduction dan akan terlihat hasil dari Data Reduct seperti terlihat pada gambar 5 .

\begin{tabular}{|l|l|l|l|}
\hline \multicolumn{5}{|c|}{ No name } \\
\hline & Reduct & Support & Length \\
\hline 1 & \{Hasil Tes\} & 60 & 1 \\
\hline 2 & \{Pendidikan\} & 20 & 1 \\
\hline
\end{tabular}

Gambar 6 :Result Of Reduction

Setelah melakukan proses reduction, langkah terakhir adalah mencari "General Rules" atau keputusan dari Information System yang diproses dengan cara "RightClick" Icon Reduct lalu General Rules, dan untuk melihat hasil atau dari Decision System yang diproses seperti terlihat pada gambar 6.

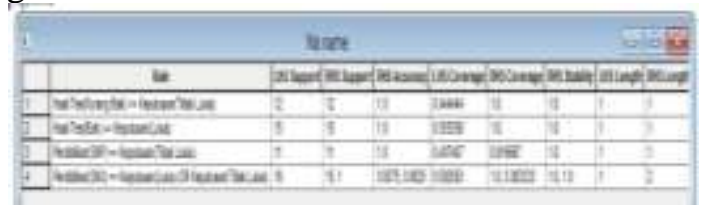

Gambar 6 Hasil Atau Rule dari Rough Set 


\section{SIMPULAN DAN SARAN}

\subsection{Simpulan}

Berdasarkan analisa dan pengujian menggunakan Software Rosetta pada UD.ROMI, maka dapat diambil beberapa kesimpulan sebagai berikut :

1. Aplikasi Rosetta mampu mengatasi persoalan-persoalan dalam proses pencarian hasil keputusan, dari pada melakukan pencarian hasil secara manual karena kesalahan dalam proses pencarian oleh Administrator.

2. Hasil penelitian ini adalah menghasilkan suatu Rules (aturan) yang dapat dimanfaatkan untuk mengambil kebijakan pengambilan keputusan di masa yang akan datang dengan cara melakukan pengolahan data yang didapatkan UD.ROMI. Pengekstrakan data dilakukan dengan menggunakan program aplikasi Rossetta.

\subsection{Saran}

Saran-saran yang dapat diusulkan sehubungan dengan penelitian ini adalah:

1. Seorang Administrator hendaknya selalu memperhatikan, memantau dan mempelajari kejadian-kejadian yang terjadi di lapangan agar tidak terjadi kesalahan dalam pemilihan calon pekerja. Salah satu caranya dapat dilakukan dengan terjun langsung untuk memantau keadaan di lapangan.

2. Bagi pembaca yang membaca tesis ini diharapkan kritikan dan sarannya untuk kesempurnaan karya ini di masa yang akan datang.

3. Bagi pembaca yang ingin melanjutkan penelitian ini lebih rinci dapat dilanjutkan sesuai dengan klasifikasi data yang telah diuraikan pada Bab IV.

4. Hasil penelitian ini diharapkan bagi Administrator penerimaan calon pegawai UD.ROMI dapat dijadikan pedoman untuk mengambil kebijakan dalam penerimaan pegawai di masa yang akan datang.

\section{DAFTAR PUSTAKA}

Chen Rung-Ching, Cheng Kai-Fan and Hsieh Chia-Fen Hsieh. 2009. Using rough set and support vector Machine for network intrusion detection.
Taiwan : Department of Information Management Chaoyang University of Technology Taichung Country.

Ginanjar Angga Mabrur dan Riani Lubis. 2012. Penerapan data mining untuk memprediksi kriteria nasabah kredit. Bandung : Program Studi Teknik Informatika Fakultas Teknik dan Ilmu Komputer Universitas Komputer Indonesia.

Nordin .M .A Rahman, et al. 2011.Applying Rough Set Theory in Multimedia Data Classification.Malaysia : Universiti Sultan Zainal Abidin.

Nurhayati. 2014. Metode rough set untuk melihat perilaku suami yang menjadi akseptor kb vasektomi. Sumatera Utara : Program Studi Teknik Informatika, STMIK KAPUTAMA BINJAI.

Kom, HARIYADI S. "PENGEMBANGAN SISTEM PAKAR BERBASIS ATURAN UNTUK MENENTUKAN MATA KULIAH YANG AKAN DIAMBIL ULANG (REMEDIAL) DENGAN METODE FORWARD CHAINING." Menara Ilmu 10.60-65 (2017).

Sucipto Adi. 2015. Prediksi kredit macet melalui perilaku nasabah Pada koperasi simpan pinjam dengan menggunakan Metode algoritma klasifikasi c4.5. Fakultas Sains dan Teknologi UNISNU Jepara.

Tripathy B. K, et al. 2011. A framework for intelligent medical diagnosis using rough set with formalconcept analysis. India : School of Computing Science and Engineering, VIT University.

Kumar Soumen Pati and Asit Kumar Das. 2013. Constructing minimal spanning tree based on rough set theory for gene selection. Department of Computer Science/Information Technology. 